\title{
Anticancer activity of Astragalus polysaccharide in human non-small cell lung cancer cells
}

Chao-Yan Wu' ${ }^{1}$ Yuan Ke², Yi-Fei Zeng ${ }^{2}$, Ying-Wen Zhang ${ }^{1}$ and Hai-Jun Yu²*

\begin{abstract}
Background: We have reported that Chinese herbs Astragalus polysaccharide (APS) can inhibit nuclear factor kappaB (NF-kB) activity during the development of diabetic nephropathy in mice. NF-kB plays important roles in genesis, growth, development and metastasis of cancer. NF-KB is also involved in the development of treatment resistance in tumors. Here we investigated the antitumor activity of APS in human non-small cell lung cells (A549 and NCI-H358) and the related mechanisms of action.

Methods: The dose-effect and time-effect of antitumor of APS were determined in human lung cancer cell line A549 and NCl-H358. The inhibition effect of APS on the P65 mRNA and protein was detected by reverse transcriptasePCR (RT-PCR) and Western blot in A549 cells respectively. The inhibition effect of APS on the p50, CyclinD1 and Bcl-xL protein was detected by Western blot in A549 cells respectively. The effect of APS on NF-kB transcription activity was measured with NF-KB luciferase detection. Finally, the nude mice A549 xenograft was introduced to confirm the antitumor activity of APS in vivo.

Results: Cell viability detection results indicated that APS can inhibit the proliferation of human lung cancer cell line A549 and NCl-H358 in the concentration of 20 and 40 mg/mL. NF-KB activator Phorbol 12-myristate13-acetate (PMA) can attenuate the antitumor activity of APS in both cell lines, but NF-KB inhibitor BAY 11-7082 (Bay) can enhance the effect of APS in both cell lines. In vivo APS can delay the growth of A549 xenograft in BALB/C nude mice. APS can down-regulate the expression of P65 mRNA and protein of A549 cells and decrease the expression of p50, CyclinD1 and $\mathrm{BCl}-\mathrm{xL}$ protein. The luciferase detection showed that the APS could reduce the P65 transcription activity in A549 cells. PMA can partially alleviate the inhibition activity of P65 transcription activity of APS in A549 cells, and Bay can enhance the down-regulation of the P65 transcription activity induced by APS in A549 cells.
\end{abstract}

Conclusion: APS has a significant antitumor activity in human lung cancer cells A549 and NCl-H358. NF-KB inhibition may mediate the antitumor effect.

Keywords: Astragalus polysaccharide, Anticancer activity, Non-small cell lung cancer cells, NF-kB

\section{Background}

Cancer is a major public health problem worldwide [1]. Surgery, radiation, and chemotherapy are the standard cancer therapies. For advanced tumors, chemotherapy is the treatment of choice, which is mostly associated

\footnotetext{
*Correspondence: doctoryhj@126.com

2 Department of Radiation and Medical Oncology, Zhongnan Hospital of Wuhan University, Donghu Road 169\#, Wuchang District, Wuhan 430071, Hubei, China

Full list of author information is available at the end of the article
}

with severe adverse events. Development of new antitumor drugs with no or low toxicities is on the agenda. Traditional Chinese Medicine (TCM) and herbal medicines have been used in the treatment of cancer for 1000 of years in China, Japan, South Korea, and other Asian countries. Numerous studies have reported that Chinese herb medicines acting as adjuvant therapy can enhance the efficacy and decrease the side effects during the cancer treatment with chemo- and radio-therapy [2]. In the search for new cancer therapeutics with low toxicity and 
few side effects, TCM shows promise. But TCM is often considered as the alternative medicine among western scholars, and the rationale and method between TCM and Western Medicine are totally different. The reluctance of western academia on TCM is mainly on account of the lack of clinical and pre-clinical studies [3].

In China, one commonly used herb, Astragalus membranaceus, has a long history of use in Traditional Chinese Medicine. It is now commonly used as an immunomodulating agent in mixed herbal decoctions. The active pharmacological constituents of radix A. membranaceus include various polysaccharides, saponins, and flavonoids [4]. Among these, Astragalus polysaccharides (APS) has been most widely studied, mainly on their immunopotentiating properties, such as promoting dendritic cell maturation and acting as an effective adjuvant in vaccines [5]. Additionally, clinical studies showed that Astragalus polysaccharides could increase the effectiveness of platinum-based chemotherapy when combined with chemotherapy [6] and improve the quality of life in patients with advanced non-small cell lung cancer (NSCLC) [7]. Basic research indicates that Astragalus saponins could induce growth inhibition and apoptosis in human colon cancer cells and tumor xenografts [8]. Another study reported that total saponins of $A$. membranaceus (AST) possess potential antitumorigenic effects in human colon cancer cells and tumor xenografts through modulation of both mTOR and ERK signaling pathways [9]. But more studies indicated that the antitumor activity of APS may depend on its function of immune regulation $[10,11]$. While there is a growing body of evidence suggesting the antitumor activity of APS, it is not well established whether APS can exert an effect of antitumor activity independent of its function of immune regulation or not.

NF- $\mathrm{kB}$ is a collective designation for a family of structurally-related and evolutionarily-conserved transcription factors that control the expression of numerous genes that play key roles in growth, apoptosis, tumorigenesis, differentiation, embryonic development, tumor metastasis and immune and inflammatory responses. Based on reports of NF- $\mathrm{kB}$ constitutive activation in numerous hematologic malignancies [12] and solid tumors, including breast and prostate tumors, melanoma and pancreatic cancer $[13,14]$, a role for NF- $k B$ is now well established in multiple aspects of cancer development, progression, and treatment resistance [15]. Thus, NF- $\mathrm{kB}$ is a promising target of cancer therapy [16].

Among malignant cancers, lung cancer accounts for the highest mortality worldwide. Recent studies with animal models and cell culture systems have well established the relations between NF- $\mathrm{kB}$ and lung carcinogenesis, highlighting the significance of targeting the
NF- $\mathrm{kB}$ signaling pathway for lung cancer treatment and chemoprevention [17]. Although lung tumors are histologically heterogeneous, tumor samples obtained from lung cancer patients showed high levels of NF- $\mathrm{KB}$ activation in both small cell lung cancer (SCLC) and NSCLC, and NF- $\mathrm{kB}$ activation is significantly associated with disease advancement in TNM stages and poor prognosis in lung cancer patients [18]. NF-KB is a positive mediator of cell growth and proliferation, which serves as a negative mediator of cell apoptosis. Activation of NF- $\mathrm{kB}$ upregulates expression of its responsive genes in cancer cells; these genes include proliferative genes (such as Cyclins D and E), anti-apoptotic genes (such as Bcl-XL, CIAP1, cIAP2, XIAP, A20, TRAF-2 and c-FLIP) and proangiogenesis genes (such as VEGF). Additionally, NF- $\mathrm{kB}$ is constitutively activated in a variety of cancers; both chemotherapeutics and radiation induce NF- $\mathrm{KB}$ activation in cancer cells, thereby contributing to resistance to these therapies [19]. Thus, it is assumed that inhibition of NF-kB will increase the efficacy of anticancer therapeutics.

Inhibition of NF- $\mathrm{kB}$ signaling with various approaches has been shown to augment the efficacy of chemotherapeutics and radiation in killing cancer cells in vitro and in vivo [17]. We have reported that APS can inhibit the NF- $\mathrm{kB}$ activity during the development of diabetic nephropathy in mice [20]. Here, the present study investigated the antitumor activity of APS in human lung cancer cells A549 and NCI-H358 and whether its antitumor activity is mediated by NF- $\mathrm{kB}$ activity inhibition. Results showed that APS can significantly inhibit the proliferation of A549 and NCI-H358 cells and down-regulate p65 and p50 expression and NF- $\mathrm{kB}$ transcription activity.

\section{Methods \\ Materials}

Human non-small lung cancer cell A549 and NCIH358 were purchased from CCTCC (China Center for Type Culture Collection, Wuhan, China). APS injection was purchased from Tianjing Cinorch Pharmaceuticals Company. The MTS reagent (3-(4,5-dimethylthiazol2-yl)-5-(3-carboxymethoxyphenyl)-2-(4-sulfophenyl)$2 \mathrm{H}$-tetrazolium) was purchased from Promega (Madison, WI, USA). Antibodies for p65, p50 and Bcl-xL were obtained from Santa Cruz Biotechnology (Santa Cruz, CA, USA); antibodies for $\beta$-actin were obtained from Boster Biotechnology (Wuhan, China). The pNF-kB-Luc reporter construct was obtained from BD Biosciences Clontech (Palo Alto, CA, USA). PMA (Sigma-Aldrich, MO, USA) was dissolved in DMSO and used at a final concentration of $50 \mathrm{ng} / \mathrm{mL}$. Bay (Sigma-Aldrich, MO, USA) was dissolved in DMSO and used at a final concentration of $10 \mu \mathrm{M}$. 


\section{Cell culture and cell viability assay}

A549 cells and NCI-H358 were cultivated in F-12K Medium and RPMI respectively supplemented with $10 \%$ fetal calf serum, 100 units/mL of penicillin, and $100 \mu \mathrm{g} /$ $\mathrm{mL}$ of streptomycin. Cells were routinely grown under a humid environment at $37^{\circ} \mathrm{C}, 5 \% \mathrm{CO}_{2}$, and passaged twice a week. Cell viability was analyzed using the MTS assay following the manufacturer's protocol. Briefly, cells were plated in each well of a 96-well tissue culture plate with $100 \mu \mathrm{L}$ of medium (3000/well). Cells became 40-50\% confluent after $24 \mathrm{~h}$ of incubation. The medium was then replaced with $100 \mu \mathrm{L}$ of fresh medium containing different concentrations of APS and DMSO for various periods of time with or without the $12 \mathrm{~h}$ pre-incubation of the NF- $\mathrm{kB}$ activator PMA or NF- $\mathrm{kB}$ inhibitor Bay. The MTS assay was performed after a designated period of time using the protocol provided by Promega. Twenty microliters of MTS solution were added to each well using a multiple tip-pipette, and cells were incubated at $37^{\circ} \mathrm{C}$ for $1-2 \mathrm{~h}$. The optical density of each well was then read at $490 \mathrm{~nm}$. The data were expressed as a percentage of the values obtained from cells cultured under the same conditions without drug.

\section{Tumor growth xenograft study}

Six-week-old inbred female BALB/C nude mice were obtained from Hubei Provincial Laboratory Animal Center. The study was approved by The Animal Care and Welfare Committee of Zhongnan Hospital of Wuhan University. The animals were fed and cared for according to the Guiding Principles for Care and Use of Laboratory Animals of Europe. A549 lung adenocarcinoma cells $\left(5 \times 10^{6}\right)$ were subcutaneously inoculated in the upper left flank on day 1 . When the diameters of the tumors were $5 \mathrm{~mm}$, the mice were randomly divided into negative control, APS, and positive control ( $\mathrm{n}=8$ each) groups. Mice in the negative control (NS) group were administered NS (normal saline) for 30 days through peritoneal injection. Mice in APS group were administered with $300 \mathrm{mg} / \mathrm{kg}$ per day for 30 days. Mice in the positive control group were injected intra-peritoneally with $8 \mathrm{mg} /$ $\mathrm{kg}$ Cisplatin (DDP) once a week for 3 weeks. Tumor size was measured using calipers every 3 days, and the volume was calculated using the following formula: $\left(\mathrm{L} \times \mathrm{W}^{2}\right) / 2$, where $\mathrm{L}$ equals length and $\mathrm{W}$ equals width. Mice were euthanized on day 30 with pentobarbital injection.

\section{RT-PCR and Western blot measurement}

RT-PCR was used to detect the expression level of p65 mRNA. Western blot were applied to measure the expression levels of p65, p50, CyclinD1 and Bcl-xL protein.
Total RNA was isolated from A549 cells using TRIzol reagent and reverse-transcribed with the SuperScript II kit (Invitrogen) following the manufacturer's protocol. The cDNA was then subjected to PCR amplification with the following primers: p65 forward, 5'-GGGAAGGAACGCTGTCAGAG-3' , and p65 reverse, 5' CTCAGGGTACTCCATCA-3', beta-actin forward, 5'-GCATGGAGTCCTGTGGCAT- ${ }^{\prime}$, and beta-actin reverse, 5'-CTAGAAGCATTTGCGGTGG-3'. The PCR conditions and thermal cycles were as follows: initial denaturation at $94{ }^{\circ} \mathrm{C}$ for $5 \mathrm{~min}$, then denature at $94{ }^{\circ} \mathrm{C}$ for $30 \mathrm{~s}$, anneal at $58^{\circ} \mathrm{C}$ for $60 \mathrm{~s}$, extend at $72{ }^{\circ} \mathrm{C}$ for $45 \mathrm{~s}$ with 25 cycles, finally extension at $72{ }^{\circ} \mathrm{C}$ for $10 \mathrm{~min}$. The PCR products were separated in a $1.5 \%$ agarose gel containing ethidium bromide and visualized under UV light.

Western blot analysis was performed to detect the protein expression level of p65 and Cyclin D1. In brief, cells were lysed in a buffer containing $50 \mathrm{mM}$ Tris, $\mathrm{pH}$ 7.4, $50 \mathrm{mM} \mathrm{NaCl}, 0.5 \%$ NP-40, $50 \mathrm{mM} \mathrm{NaF}, 1 \mathrm{mM} \mathrm{Na}_{3} \mathrm{VO}_{4}$, $1 \mathrm{mM}$ phenylmethylsulfonyl fluoride, $25 \mathrm{mg} / \mathrm{mL}$ leupeptin, and $25 \mathrm{mg} / \mathrm{mL}$ aprotinin. The lysates were centrifuged at $15,000 \mathrm{~g}$ for $15 \mathrm{~min}$ and the supernatants were collected. Proteins were separated by SDS-PAGE, transferred to a PVDF membrane, and blotted with specific antibodies against proteins of interest, as described in the figure legends.

\section{NF-KB activity assay}

The NF-kB-luciferase plasmid construct (pNF-kB-Luc, BD Biosciences Clontech, Palo Alto, CA) was used to study NF-kB activity. A549 cells $\left(2 \times 10^{6}\right)$ were initially seeded in $75-\mathrm{mm}$ flasks containing $5 \mathrm{~mL}$ of DMEM medium with supplements. Cells reached $80 \%$ confluence after $24 \mathrm{~h}$ of incubation and were washed once with cold PBS. Lipofectin-DNA complexes were prepared by incubating $25 \mu \mathrm{L}$ of lipofectin reagent with $4 \mu \mathrm{g}$ of reporter plasmid DNA in $0.2 \mathrm{~mL}$ of RPMI-1640 medium without supplements for $40 \mathrm{~min}$ at room temperature $\left(22{ }^{\circ} \mathrm{C}\right)$. The lipofectin-DNA complexes were diluted in $1 \mathrm{~mL}$ serum-free RPMI-1640 medium, added to the cells, and incubated for $5 \mathrm{~h}$ at $37^{\circ} \mathrm{C}$. Four milliliters of complete RPMI-1640 medium (with 15\% FBS) were then added and the cells incubated overnight. The cells were then plated into 24-well plates at a density of 100,000 per well. After $48 \mathrm{~h}$ of transfection, cells were treated with APS and DMSO for $6 \mathrm{~h}$ with or without the $6 \mathrm{~h}$ pre-incubation of the NF- $\mathrm{kB}$ activator PMA or NF- $\mathrm{kB}$ inhibitor Bay. The manufacturer's protocol for assaying luciferase activity was followed with minor modifications. Cells were washed once with cold PBS in the absence of $\mathrm{Mg}^{2+}$ and $\mathrm{Ca}^{2+}$ and lysed with $100 \mu \mathrm{L}$ of reporter lysis buffer (Promega, Madison, WI). The lysate was briefly centrifuged and cell particulates were removed. The protein 
concentration was determined using a kit from Pierce (Rockford, IL). Luciferase assays were performed using Turner Biosystems Modulus Microplate Multimode Reader with $30 \mu \mathrm{L}$ of luciferase assay reagent mixed with
$50 \mu \mathrm{L}$ of protein extract. The relative light readings were normalized for the amount of protein in each sample, and the results presented as relative changes in luciferase activity.
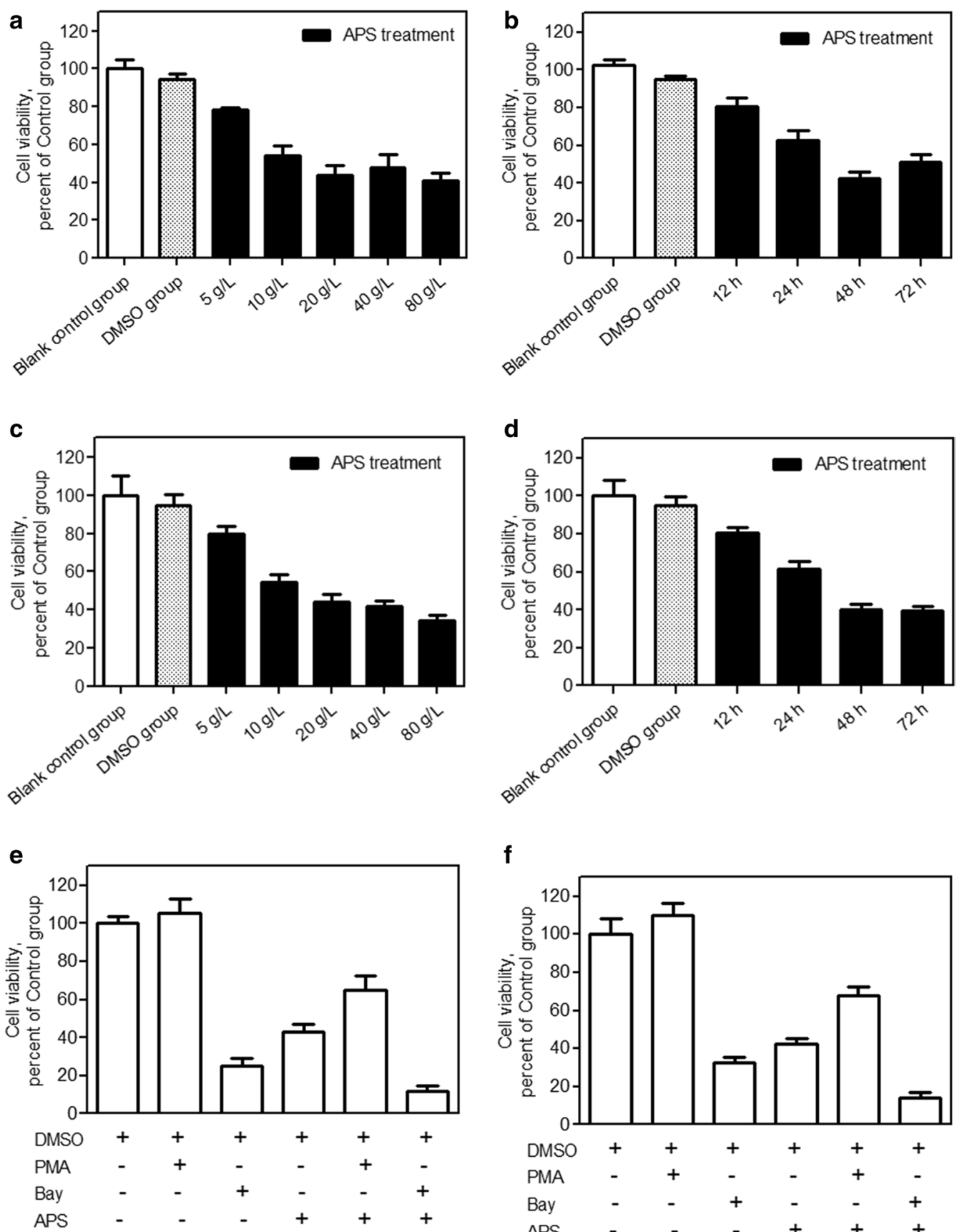

f

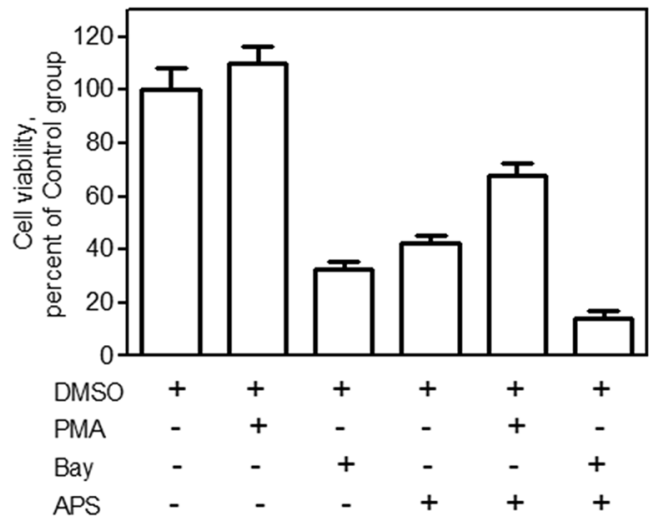

Fig. 1 APS inhibits A549 and NCl-H358 cell growth in a concentration- and time-dependent manner. A549 cells were treated with different concentration of APS for $24 \mathrm{~h}$ a and with $20 \mathrm{mg} / \mathrm{mL}$ APS for different time $\mathbf{b}, \mathrm{NCl}-\mathrm{H} 358$ cells were treated with different concentration of APS for $24 \mathrm{~h}$ c and with $20 \mathrm{mg} / \mathrm{mL}$ APS for different time d. The growth inhibition of $20 \mathrm{mg} / \mathrm{mL}$ APS on A549 and NCI-H358 cells with or without the $12 \mathrm{~h}$ preincubation of the NF-kB activator PMA or NF-kB inhibitor Bay was shown in e, f respectively. Representative data of three independent experiments are shown 


\section{Statistics analysis}

One-way ANOVA was used for assessing the differences among groups of data, followed by Dunnett analysis with $\mathrm{p}<0.05$ as the level of statistical significance. All statistical analyses were performed with Graphpad Prism software Version 5.0 (San Diego, CA).

\section{Results}

\section{Effects of APS on the viability of A549 and NCl-H358 lung} cancer cells

We first examined the effects of APS on the viability of A549 and NCI-H358 cells. As shown in Fig. 1a, b, APS can inhibit A549 cell growth in a concentration- and time-dependent manner. APS at $5 \mathrm{mg} / \mathrm{mL}$ showed minor toxicity, and at $80 \mathrm{mg} / \mathrm{mL}$ reduced cell viability by around $50 \%$. The toxicity of APS at concentrations of 20,40 , and $80 \mathrm{mg} / \mathrm{mL}$ showed no difference. Time-course studies revealed the peak toxicity of $20 \mathrm{mg} / \mathrm{mL}$ of APS after $48 \mathrm{~h}$ incubation. Figure 1c, d showed that APS has the same inhibition effect of viability in NCI-H358 cells. To investigate the role of NF- $\mathrm{kB}$ activity in the antitumor activity of APS in two cell lines, we introduced the NF- $k B$ activator PMA or NF-kB inhibitor Bay. Compared with the APS group, NF- $k B$ activator PMA can attenuate the proliferation inhibition of APS in two cell lines, and NF- $\mathrm{kB}$ inhibitor Bay can enhance the proliferation inhibition of APS in two cell lines (Fig. 1e, f).

\section{Effects of APS on A549 xenograft growth}

We further investigated the inhibitory effect of APS on the tumor growth of A549 cells in vivo. DDP was introduced as the positive control (Fig. 2). Two-way ANOVA analysis indicated that administration of APS and DDP to A549 bearing mice resulted in remarkably delayed tumor growth in comparison with the control group $(\mathrm{p}<0.001)$. The growth inhibition effect was apparent after 18 days of treatment (DDP vs Control, $\mathrm{p}<0.001$ on day $18-30$; APS vs Control, $\mathrm{p}<0.05$ on day $21, \mathrm{p}<0.001$ on day 24-day 30). DDP treatment was associated with more potent antitumor activity (DDP vs APS, $\mathrm{p}>0.05$ on day $0-15, \mathrm{p}<0.05$ on day $18, \mathrm{p}<0.001$ on day $21-30$ ), the inhibitory effect of tumor growth in the DDP group was stronger than that seen in the APS group.

\section{Effects of APS on the expression of p65 and p50 in A549 cells}

We have reported that APS can down-regulate the expression of p65 mRNA and protein during the development of diabetic nephropathy in mice. It has not been reported whether APS can inhibit the expression of p65 mRNA and protein in human tumor cells. Here we examined the expression of p65 mRNA and protein in A549 cells treated with APS. Reverse transcription-PCR
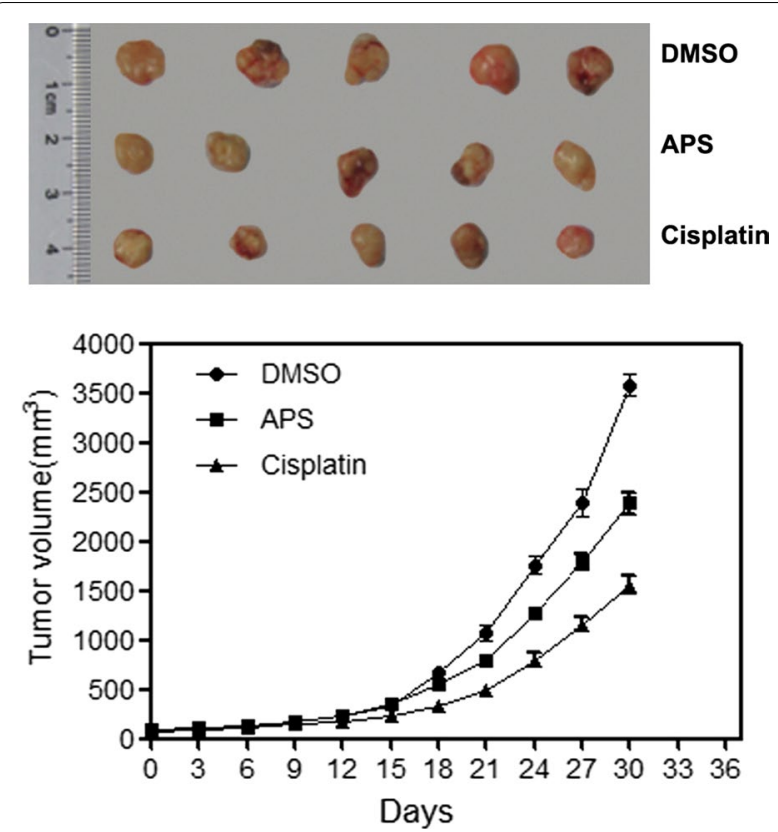

Fig. 2 APS delays the growth of A549 xenograft in BALB/C nude mice. A549 lung adenocarcinoma cells $\left(5 \times 10^{6}\right)$ were subcutaneously inoculated in the upper left flank of mice, the mice were randomly divided into three group ( $n=8$ each): Negative control (treated with normal saline), APS (300 mg/kg per day for 30 days through i.p injection), and positive control ( $8 \mathrm{mg} / \mathrm{kg}$ DDP once a week for 3 weeks). Tumor size was recorded every 3 days and the volume was calculated using the following formula: $\left(L \times W^{2}\right) / 2$, where $L$ equals length and $W$ equals width

assay (Fig. 3a) revealed that p65 mRNA was decreased in A549 cells treated with APS for $24 \mathrm{~h}$ (APS group vs Control group, $35.87 \%$ vs $100 \%, p<0.05$ ). Western blot analysis (Fig. 3b) demonstrated that APS can reduce the expression of p65 in A549 cells after $48 \mathrm{~h}$ incubation (APS group vs Control group, $49.10 \%$ vs $100 \%$, $p<0.05)$. We further detected the p50 expression level in the nuclei of A549 cells treated with $20 \mathrm{mg} / \mathrm{mL}$ APS. Western blot analysis (Fig. 3c) indicated that APS can decrease the expression level of p50 protein in the nuclei of A549 cells (APS group vs Control group, $62.30 \%$ vs $100 \%, p<0.05)$. These data show that APS can inhibit the expression levels of p65 and p50 in human cancer cells.

\section{Effects of APS on the activity of NF-KB in A549 cells}

We first showed that APS can decrease the expression of p65 mRNA and protein in A549 cells. Next, we determined whether APS can down-regulate the activity of NF-kB in A549 cells (Fig. 4). We introduced NF-kBluciferase plasmid construct to detect the effect of APS on the activity of NF- $\mathrm{kB}$. Luciferase activity detection showed that APS at the concentration of $20 \mathrm{mg} / \mathrm{mL}$ can 
a

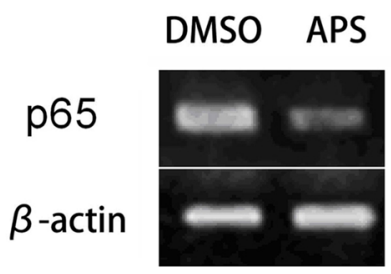

b

p65

$\beta$-actin

DMSO

APS
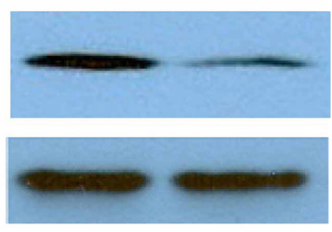

C

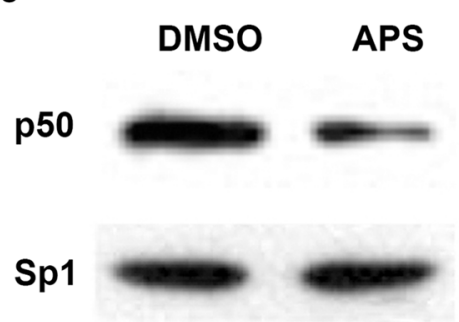

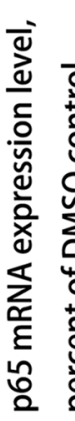

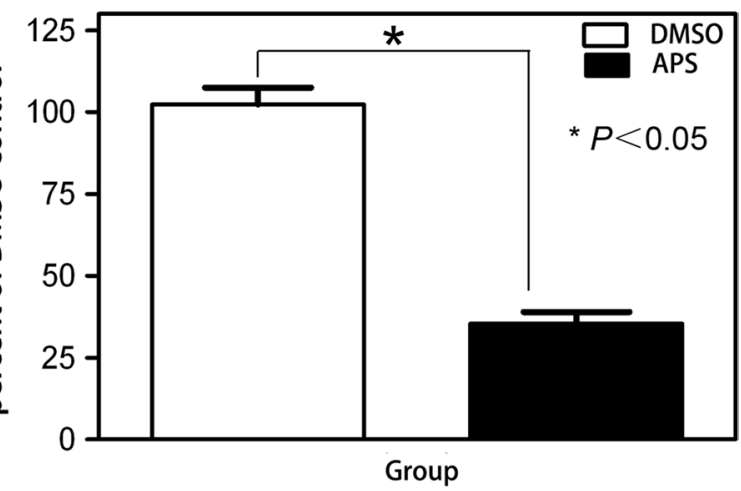

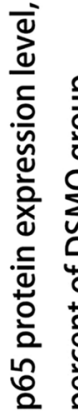
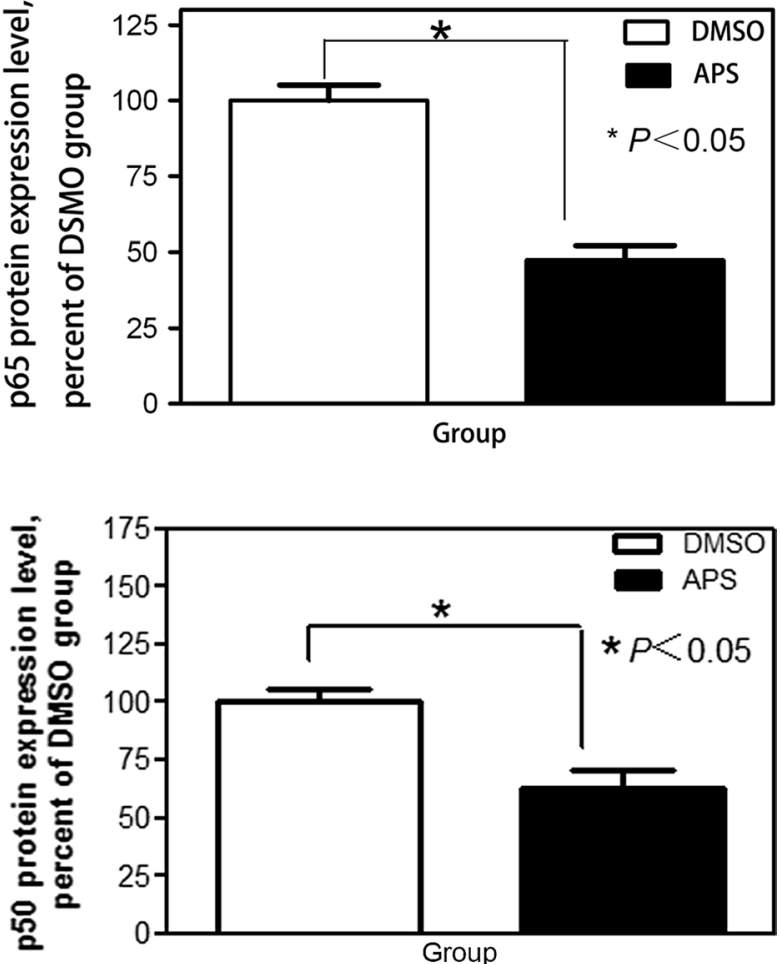

Fig. 3 The downregulation of APS on p65 and p50 expression in A549 cells. The RT-PCR (reverse transcription PCR) and Western blot were applied to measure the expression level of p65 mRNA and protein $\mathbf{a}, \mathbf{b}$. Western blot was applied to measure the expression level of p50 protein in nuclei $\mathbf{c}$. Representative data of three independent experiments are shown

decrease NF- $\kappa \mathrm{B}$ activity after $6 \mathrm{~h}$ of treatment (APS group vs Control group, $53.19 \%$ vs $100 \%, p<0.05)$. Six hours pre-incubation with NF-kB activator PMA or NF- $\mathrm{kB}$ inhibitor Bay, PMA can alleviate the inhibition effect of luciferase activity of APS in A549 cell line, and Bay had a synergistic inhibition effect of luciferase activity with APS in A549 cell line. These data are consistent with the result of APS on the expression of p65 mRNA and protein in A549 cells, which showed that NF- $\mathrm{KB}$ activity plays an important role in the antitumor activity of APS in human lung cancer cells lines.
Effects of APS on the expression of CyclinD1 and Bcl-xL in A549 cells

The covalently modified, activated free form of NF- $\mathrm{KB}$ is transported to the nucleus and binds to target DNA sequences, termed $\mathrm{KB}$ sites (GGGRNYYYCC), and recruits many chromatin remodeling factors to the NF- $\mathrm{KB}$ target promoters (Cyclin D1 and Bcl-xL), eventually leading to the activation of their target genes implicated in cell proliferation, invasion and cell death. Here we measured the effect of APS on CyclinD1 and Bcl-xL protein in A549 cells. After $72 \mathrm{~h}$ treatment of $20 \mathrm{mg} / \mathrm{mL}$ 


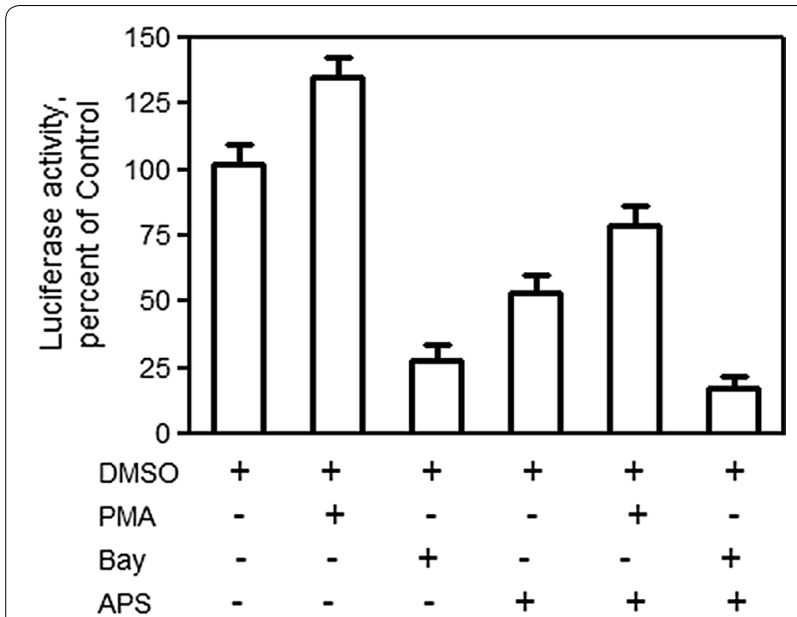

Fig. 4 The inhibtion of APS on NF-KB transcription activity in A549 cells. The NF-kB-luciferase plasmid construct (pNF-kB-Luc) was used to study NF-KB activity. pNF-KB-Luc were transfected into the A549 cells, the cells then were treated with APS and DNSO for $6 \mathrm{~h}$. The luciferase activity of NF-kB was determined according the protocol. Representative data of three independent experiments are shown

APS, the CyclinD1 expression level in the APS group decreased by $45.01 \%$ compared with the DMSO group (Fig. $5 \mathrm{a}, p<0.05$ ), the $\mathrm{Bcl}-\mathrm{xL}$ protein expression level in the APS group reduced to $59.23 \%$ compared with DMSO group (Fig. 5b, $p<0.05$ ).

\section{Discussion}

In recent years, APS has been shown to enhance immune function in micro environments [11] and inhibit colon cancer cell growth in vivo [9]. Many studies reported that APS can improve immune functions, but it is unclear whether the antitumor activity of APS is dependent or independent on immune function. Here we performed the MTS assay in human non-small cell lung cancer cells (A549 and NCI-H358) after APS treatment. Results indicate that APS can inhibit proliferation of A549 and NCI$\mathrm{H} 358$ cells in vitro, reduce the expression of $\mathrm{p} 65$ and p50, down-regulate the transcription activity of NF- $\mathrm{KB}$, and decrease the expression of CyclinD1 and Bcl-xL protein. Further studies showed that APS can delay the tumor growth of A549 xenograft in vivo. These data show the antitumor activity in human non-small cell cancer cells for the first time, confirming that APS can suppress human tumor cells in vitro, independently of the immune system.

The present study first indicated that APS has antitumor activity in human non-small lung cancer cells. We introduced the MTS method to investigate the proliferation effect of APS on human A549 and NCI-H358 cells. Data showed that APS has concentration- and timedependent antitumor activity in A549 and NCI-H358 cells, with the antitumorigenic effects observed in the A549 xenograft. Other studies also suggest that APS can

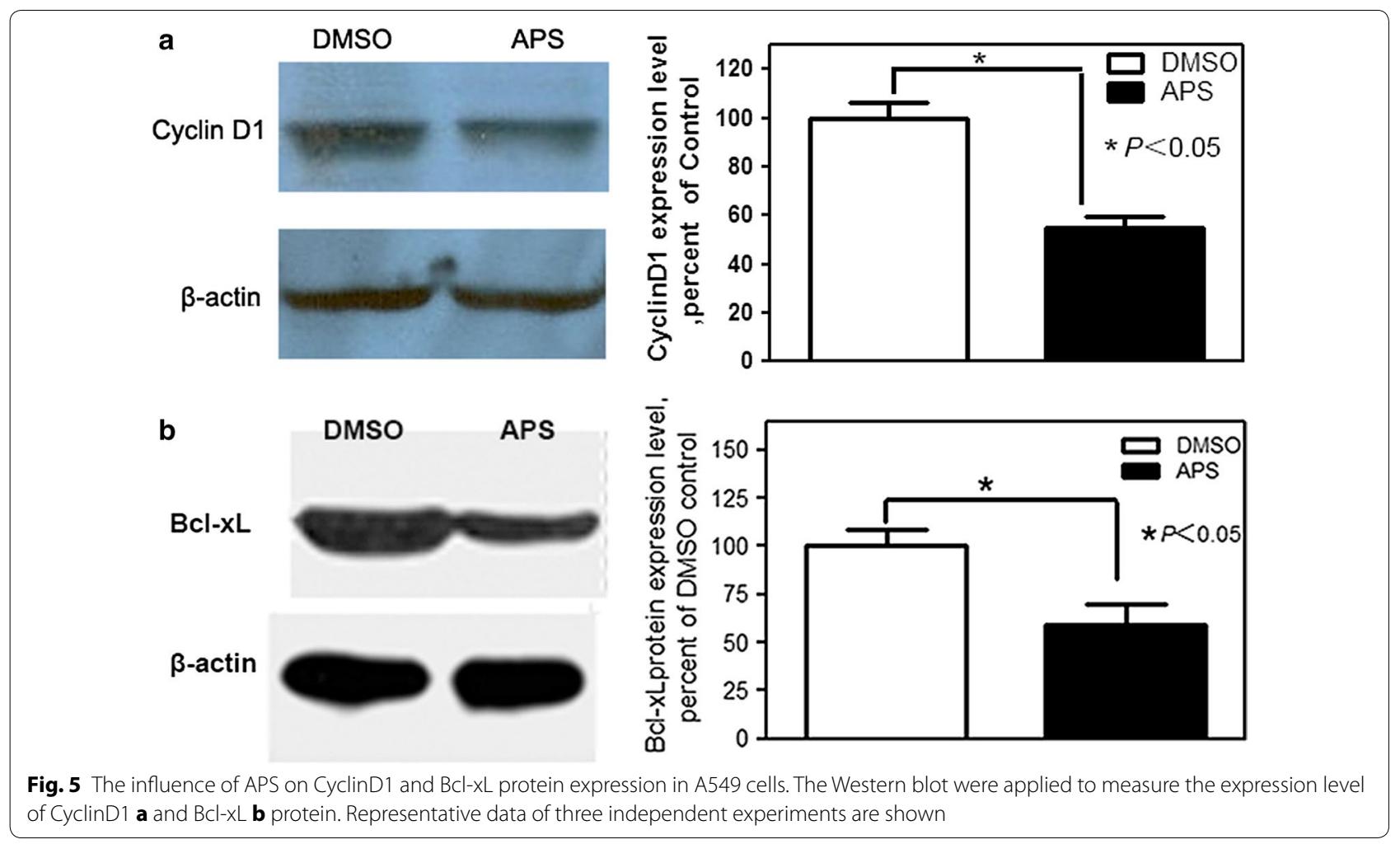


enhance the antitumor effect of chemotherapeutic agents and diminish the side effects of chemotherapy [2]. Guo et al. reported that APS injection can raise the quality of life and survival of advanced non-small cell lung cancer patients treated with vinorelbine and cisplatin [7]. In 2007, a report showed that Astragalus saponins can inhibit HT-29 human colon cancer cell proliferation through accumulation in S phase and G2/M arrest, and promote apoptosis in HT-29 cells through Caspase 3 activation and poly (ADP-ribose) polymerase cleavage. The following study confirmed these results [9]. Other researchers also demonstrated that Astragalus mongholicus injection may inhibit proliferation and induce apoptosis in human breast cancer cell lines [21]. Our study clarified for the first time the antitumor effect in human non-small cell lung cancer cells in vitro and in vivo.

The mechanism of antitumor activity of APS is multiple and complex, although several studies have demonstrated its effect. Our study showed that APS can down-regulate p65 and p50 expression, and decrease the transcription activity of NF- $\mathrm{kB}$. We also found that NF- $\mathrm{kB}$ activator PMA can attenuate the antitumor activity of APS in human lung cancer cell lines, NF- $\mathrm{kB}$ inhibitor Bay can enhance the antitumor activity of APS in the two cell lines. NF- $\mathrm{kB}$ is a key transcription factor involved in several pathways in cancer, which is constitutively active in most cancers. The role of NF- $\mathrm{kB}$ in the carcinogenesis, development, proliferation, and treatment resistance has been confirmed [22]. Thus, the constitutive activation of NF- $\mathrm{kB}$ has emerged as one of the most attractive targets for intervention and treatment of cancer. We have reported that APS can inhibit the NF- $\mathrm{kB}$ activity during the development of diabetic nephropathy in mice [20]. Here we found that APS can decrease NF- $k B$ activity in human non-small cell lung cancer cells for the first time. Other studies also indicated that APS can prevent tumor growth through down-regulation of the expression of Akt phosphorylation in human breast cancer cells [21], modulation of both mTOR and ERK signaling pathways [9] or Caspase 3 activation [8] in human colon cancer cells.

It was previously reported that NF- $\mathrm{kB}$ stimulates transcription of CyclinD1, a key factor involved in G1 checkpoint control and regulator of the cell cycle and apoptotic processes [23]. Hence we suspected that prevention of $\mathrm{NF}-\mathrm{kB}$ entry into the nucleus might have prevented the activation of the CyclinD1 promoter, which is responsible for active proliferation of lung cancer cells. After $72 \mathrm{~h}$ of treatment with $20 \mathrm{mg} / \mathrm{mL}$ APS, the CyclinD1 expression level in the APS group decreased by $45.01 \%$ compared with the DMSO group. NF- $\mathrm{kB}$ also can stimulate transcription of $\mathrm{Bcl}-\mathrm{xL}$, which acts as an anti-apoptotic protein by preventing the release of mitochondrial contents such as cytochrome c. Here we confirmed that the APS can reduce the protein expression level Bcl-xL in A549 cells. These data confirmed our hypothesis.

\section{Conclusions}

In brief, our study indicates that APS can inhibit the proliferation and delay the tumor growth xenograft of human non-small lung cancer cells in vivo and in vitro through the down-regulation of NF-kB activity. We will further clarify the independent antitumor activity of APS and enrich the antitumor mechanism of APS, which will benefit the development of low toxic antitumor reagents.

\begin{abstract}
Abbreviations
APS: Astragalus polysaccharide; NF-kB: nuclear factor kappaB; PMA: phorbol 12-myristate13-acetate; Bay: BAY 11-7082; TCM: Traditional Chinese Medicine; NSCLC: non-small cell lung cancer; AST: Astragalus membranaceus; mTOR: mammalian target of rapamycin; ERK: extracellular regulated protein kinases; SCLC: small cell lung cancer; BCI-XL: B-cell lymphoma-extra large; CIAP1 and CIAP2: cellular inhibitors of apoptosis protein 1 and 2; TRAF-2: TNF receptorassociated factor 2; c-FLIP: FLICE-like inhibitory protein; VEGF: vascular endothelial growth factor; DDP: cisplatin; XIAP: X-linked inhibitor of apoptosis protein.
\end{abstract}

\section{Authors' contributions}

HJY and FXZ conceived and designed the experiments. KY, HJY and CYW performed the experiments. YWZ and HJY analyzed the data. HJY, YWZ and FXZ supervised the whole experimental work and revised the manuscript. CYW and HJY wrote the paper. All authors read and approved the final manuscript.

\section{Author details \\ ${ }^{1}$ Department of Integrated Traditional Chinese Medicine and Western Medi- cine, Zhongnan Hospital of Wuhan University, Donghu Road 169\#, Wuchang District, Wuhan 430071, Hubei, China. ${ }^{2}$ Department of Radiation and Medi- cal Oncology, Zhongnan Hospital of Wuhan University, Donghu Road 169\#, Wuchang District, Wuhan 430071, Hubei, China.}

\section{Acknowledgements}

We gratefully acknowledge the manuscript revision of Dr. Jessica R. Lou.

\section{Competing interests}

The authors declare that they have no competing interests.

\section{Availability of data and materials}

Please contact authors for data request.

\section{Consent for publication \\ Not applicable.}

\section{Ethics approval and consent to participate}

The protocol about animal research of this study was reviewed and approved The Animal Care and Welfare Committee of Zhongnan Hospital of Wuhan University. There are no human participants, human data or human tissue involved in this study.

\section{Funding}

This work was partly supported by grants from National Natural Science Foundation of China (Nos. 81201755 and 81703872) and Integrated Traditional Chinese Medicine and Western Medicine Research Grants of Health and Family Planning Commission of Hubei Province.

\section{Publisher's Note}

Springer Nature remains neutral with regard to jurisdictional claims in published maps and institutional affiliations. 
Received: 18 May 2017 Accepted: 25 November 2017

Published online: 04 December 2017

\section{References}

1. Siegel RL, Miller KD, Jemal A. Cancer statistics, 2015. CA Cancer J Clin. 2015;65:5-29.

2. Qi F, Li A, Inagaki Y, Gao J, Li J, Kokudo N, et al. Chinese herbal medicines as adjuvant treatment during chemo- or radio-therapy for cancer. Biosci Trends. 2010;4:297-307.

3. Konkimalla VB, Efferth T. Evidence-based Chinese medicine for cancer therapy. J Ethnopharmacol. 2008:116:207-10.

4. Ma XQ, Duan JA, Dong TT, Tsim KW. Chemical analysis of Radix astragali (Huangqi) in China: a comparison with its adulterants and seasonal variations. J Agric Food Chem. 2002;50:4861-6.

5. Du X, Zhao B, Li J, Cao X, Diao M, Feng H, et al. Astragalus polysaccharides enhance immune responses of HBV DNA vaccination via promoting the dendritic cell maturation and suppressing Treg frequency in mice. Int Immunopharmacol. 2012:14:463-70.

6. McCulloch M, See C, Shu XJ, Broffman M, Kramer A, Fan WY, et al. Astragalus-based Chinese herbs and platinum-based chemotherapy for advanced non-small-cell lung cancer: meta-analysis of randomized trials. J Clin Oncol. 2006:24:419-30.

7. Guo L, Bai SP, Zhao L, Wang XH. Astragalus polysaccharide injection integrated with vinorelbine and cisplatin for patients with advanced nonsmall cell lung cancer: effects on quality of life and survival. Med Oncol. 2012;29:1656-62

8. Tin MM, Cho CH, Chan K, James AE, Ko JK. Astragalus saponins induce growth inhibition and apoptosis in human colon cancer cells and tumor xenograft. Carcinogenesis. 2007;28:1347-55

9. Auyeung KK, Mok NL, Wong CM, Cho CH, Ko JK. Astragalus saponins modulate $\mathrm{mTOR}$ and ERK signaling to promote apoptosis through the extrinsic pathway in HT-29 colon cancer cells. Int J Mol Med. 2010;26:341-9.

10. Liu LM, Zhang LS. Effect of Astragalus polysaccharide on the function and maturation of plasmacytoid dendritic cells from chronic myelogenous leukemia before and after treatment. Zhonghua Xue Ye Xue Za Zhi. 2010;31:740-3.

11. Li Q, Bao JM, Li XL, Zhang T, Shen XH. Inhibiting effect of Astragalus polysaccharides on the functions of CD4+ CD25 highTreg cells in the tumor microenvironment of human hepatocellular carcinoma. Chin Med J. 2012;125:786-93.

12. Rayet B, Gelinas C. Aberrant rel/nfkb genes and activity in human cancer. Oncogene. 1999;18:6938-47.

13. Carbone C, Melisi D. NF-kappaB as a target for pancreatic cancer therapy. Expert Opin Ther Targets. 2012;16(Suppl 2):S1-10.

14. DiDonato JA, Mercurio F, Karin M. NF-kappaB and the link between inflammation and cancer. Immunol Rev. 2012;246:379-400.

15. Gallardo-Perez JC, Espinosa M, Ceballos-Cancino G, Daniel A, RodriguezEnriquez S, Aviles A, et al. NF-kappaB is required for the development of tumor spheroids. J Cell Biochem. 2009;108:169-80.

16. Melisi D, Chiao PJ. NF-kappaB as a target for cancer therapy. Expert Opin Ther Targets. 2007;11:133-44.

17. Chen W, Li Z, Bai L, Lin Y. NF-kappaB in lung cancer, a carcinogenesis mediator and a prevention and therapy target. Front Biosci (Landmark Ed). 2011;16:1172-85.

18. Karin M, Greten FR. NF-kappaB: linking inflammation and immunity to cancer development and progression. Nat Rev Immunol. 2005;5:749-59.

19. Nakanishi C, Toi M. Nuclear factor-kappaB inhibitors as sensitizers to anticancer drugs. Nat Rev Cancer. 2005;5:297-309.

20. Zhang YW, Wu CY, Cheng JT. Merit of Astragalus polysaccharide in the improvement of early diabetic nephropathy with an effect on mRNA expressions of NF-kappaB and IkappaB in renal cortex of streptozotocininduced diabetic rats. J Ethnopharmacol. 2007;114:387-92.

21. Ye MN, Chen HF, Zhou RJ, Liao MJ. Effects of Astragalus polysaccharide on proliferation and Akt phosphorylation of the basal-like breast cancer cell line. Zhong Xi Yi Jie He Xue Bao. 2011;9:1339-46.

22. Chaturvedi MM, Sung B, Yadav VR, Kannappan R, Aggarwal BB. NF-kappaB addiction and its role in cancer: one size does not fit all. Oncogene. 2011;30:1615-30

23. Hu J, Colburn NH. Histone deacetylase inhibition down-regulates cyclin D1 transcription by inhibiting nuclear factor-kappaB/p65 DNA binding. Mol Cancer Res. 2005:3:100-9.

\section{Submit your next manuscript to BioMed Central and we will help you at every step:}

- We accept pre-submission inquiries

- Our selector tool helps you to find the most relevant journal

- We provide round the clock customer support

- Convenient online submission

- Thorough peer review

- Inclusion in PubMed and all major indexing services

- Maximum visibility for your research

Submit your manuscript at www.biomedcentral.com/submit
(O) BioMed Central 